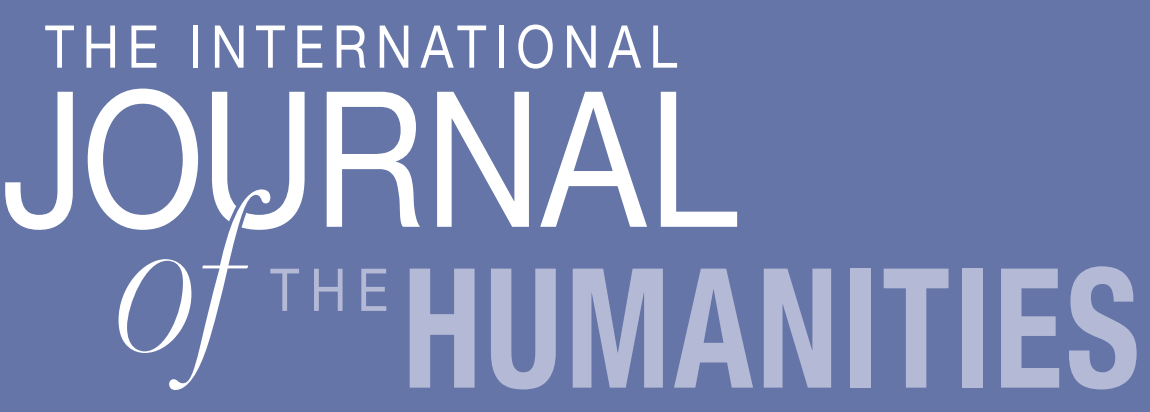

Volume 9, Number 1

Making and Managing Knowledge in the "New" Humanities: An Australian Experience

Dawn Bennett 
THE INTERNATIONAL JOURNAL OF THE HUMANITIES

http://www.Humanities-Journal.com

First published in 2011 in Champaign, Illinois, USA

by Common Ground Publishing LLC

www.CommonGroundPublishing.com

ISSN: $1447-9508$

(C) 2011 (individual papers), the author(s)

(c) 2011 (selection and editorial matter) Common Ground

All rights reserved. Apart from fair dealing for the purposes of study, research, criticism or review as permitted under the applicable copyright legislation, no part of this work may be reproduced by any process without written permission from the publisher. For permissions and other inquiries, please contact

<cg-support@commongroundpublishing.com>.

THE INTERNATIONAL JOURNAL OF THE HUMANITIES is peer-reviewed, supported by rigorous processes of criterion-referenced article ranking and qualitative commentary, ensuring that only intellectual work of the greatest substance and highest significance is published.

Typeset in Common Ground Markup Language using CGPublisher multichannel typesetting system

http://www.commongroundpublishing.com/software/ 


\title{
Making and Managing Knowledge in the "New" Humanities: An Australian Experience
}

\author{
Dawn Bennett, Curtin University, Western Australia, Australia
}

\begin{abstract}
The innovative ways in which humanities academics give shape and meaning to traditional and artistic research has attracted increasing attention as researchers address ever-more complex issues. This attention stems in part from the problematic frameworks in which academic research is situated, but it relates also to growing concerns that traditional "scientific" research approaches do not always provide an adequate model for research, including some of what is happening in the sciences. In this paper the focus is on knowledge relating to artistic research. Implications include managing the translation of artistic research into a form that can be understood (and learned from) by the wider academy, and accommodating artistic research output within research frameworks less flexible than the works they assess.
\end{abstract}

Keywords: Artistic Research, Research Frameworks, Research Management, Excellence in Research for Australia, New Humanities

\section{Introduction}

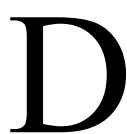

EFINITIONAL ISSUES CAN impede meaningful discussion of knowledge within the "new" humanities. In seeking to prompt such discussion, therefore, this paper begins with a brief exploration of the history of the humanities and divisions of knowledge. It then moves to the example of Australia in the adoption of a research framework that classifies knowledge into three hierarchical levels comprising 22 divisions, 157 groups and 1,238 fields of research. Against this background, the paper considers some of the implications for making and managing knowledge.

For most academics, specialisation refers to a highly intensive engagement with a particular academic field of research. Specialist areas often feature dedicated research teams, centres of excellence, journals, conferences, networks and, of course, funding. To succeed in this highly competitive research environment it is often necessary to develop a reputation of expertise within a defined specialist area. In contrast, Aristotle, who wrote on an array of subjects ranging from physics to poetry, is remembered not as a specialist but as a philosopher. This is because philosophy, in Aristotle's time, was taken to mean the broad pursuit of wisdom or knowledge by intellectual means. And yet the creation of formal divisions of knowledge can be traced back to the ancient world. In the third century BC, contemporaneous with Aristotle, Greek Stoics grouped together grammar, rhetoric and dialectics. Indeed, the concept of the liberal arts emerged during the Roman times with the identification and classification of seven liberal arts disciplines. In the Middle Ages, grammar, rhetoric and dialectics were grouped together as the trivium, and the remaining four liberal arts - arithmetic, geometry, astronomy and music - were arranged as a quadrivium of mathematical subjects. These divisions were made on the basis that "the trivium includes those aspects of the liberal arts

The International Journal of the Humanities

Volume 9, Number 1, 2011, http://www.Humanities-Journal.com, ISSN 1447-9508

(C) Common Ground, Dawn Bennett, All Rights Reserved, Permissions:

cg-support@commongroundpublishing.com 
that pertain to mind, and the quadrivium, those aspects of the liberal arts that pertain to matter" (Joseph, 2002, p. 3).

The Renaissance period saw the emergence of humanities disciplines as educational programs: as subjects to be studied and analysed rather than acted out or experienced, and with a positivist focus on the observable and analysable. This was of course a response to humanism, the intellectual movement that revived ancient learning (particularly moral philosophy, history, grammar, rhetoric and poetry) at a time of renewed interest in ancient Greek and Roman cultures. Given that humanism influenced values right across society, it is hardly surprising that it had a profound influence on learning (Levi, 1970).

\section{The Traditional and the New}

Despite the humanist movement of the Renaissance period, the humanities did not emerge as distinct fields of study until the nineteenth century, and it was only then that the term humanities came into common use. Shumway (2007, p. 1) suggests that the modern humanities disciplines are the result of three conditions:

1. a shift in the conception of knowledge that demoted texts to objects of study;

2. the break up of philosophy into the sciences; and

3. the invention of the disciplinary form itself [entailing among other things] new pedagogical spaces of the classroom and the laboratory, and new practices, such as the seminar.

The cluster of subjects we now recognise as "traditional" humanities were thus largely defined in the $19^{\text {th }}$ century. Aligned with humanist fascination with the ancient world, many of the humanities centred on studies of antiquity: classical history, language, arts, culture, philosophy and so on. Modern languages and literature were added later, and in several countries many of the arts moved to specialist institutions only to be brought back into the university system over the past 50 years or so. Contemporary and popular culture count among the subjects to have been added over that period. As Tymoczko explains, changing views of knowledge during the $20^{\text {th }}$ century

undermined the $19^{\text {th }}$-century epistemological and ideological premises of the traditional humanities and, indeed, of academe as a whole. The humanities were by and large transformed, particularly in the second half of the $20^{\text {th }}$ century, as post-positivist views of knowledge shifted inquiry away from primary research oriented toward digging out and amassing observable 'facts', to self-reflexive methods involving interrogations of perspective, premises, and the framework of inquiry itself. (2001, p. 287)

In the $21^{\text {st }}$ century, the humanities are still variously described. Each of the 56 State Humanities Councils in the United States, for example, defines the humanities in terms of activities within their region. Likewise there is little consistency between universities, which define humanities according to the courses they offer. Stanford University, which has fifteen humanities departments, describes the humanities as "the study of the myriad ways in which people, from every period of history and from every corner of the globe, process and document the human experience" (Stanford, 2010, n. p). Interestingly, Stanford's largest school is the School of Humanities and Science. Princeton is similarly home to a College of Arts and Sciences, and yet Princeton's WordNet database (Princeton, 2011, n. p) adopts a common, 
non-vocational definition of the humanities: namely "studies intended to provide general knowledge and intellectual skills (rather than occupational or professional skills)..."

Non-vocational definitions such as the one found on the Princeton database have formed the basis of many statements in defence of the humanities, which some believe "can defend themselves best by refusing to make any claims of utility" (Fish, 2008, n. p). However, this is a perilous stance in the era of the corporatised university, and it has failed to stem criticism that traditional humanities programs are "both expensive and relatively useless" (Humanities in the United States, 2010) in the job market. Such claims have contributed to the demise of many traditional humanities courses. In Australia, for example, the University of Queensland announced in 2007 that it would close its School of Humanities and Human Services altogether, abandoning its "old humanities" Bachelor of Arts program in favour of a focus on the more popular (and vocationally oriented) creative industries (Ianziti, May 2007, n. p). The need for clarification and rigorous debate is further illustrated with the example of the Australian Academy of the Humanities, which has received research funding "to chart the disposition and trends of the humanities sector in Australia ... to arrive at a nuanced understanding of the key issues facing the sector today" (AAH, 2009, n. p). Whilst these issues are crucial to understanding and managing knowledge within the new humanities, the changing research environment is equally important, and it is this to which I turn next.

The recent history of Australia's higher education sector provides an excellent, though by no means unique, example of corporatisation and research assessment. In 1982 each Australian state was required by the federal government to combine smaller Colleges of Advanced Education (CAEs), reducing the total number from 79 to 47. Many of these Colleges ran crucial courses in the humanities and education. Six years later, Australian Higher Education Policy known as the Dawkins Reform (Dawkins, 1998) required institutions with less than 2,000 students to merge with a university, as a result of which CAEs and universities were combined in 1991 to create the unified national system (UNS). Over the course of these changes almost all of Australia's arts schools amalgamated with universities and became university departments, often devolving leadership to the non-discipline leader of a larger faculty. Further cuts to higher education in the late 1990s led to additional amalgamation and far less budgetary control at departmental level (Bennett, Blom \& Wright, 2009). The results of the UNS were more complex than expected, and have particularly impacted funding for non-traditional modes of teaching such as individual music tuition and small group teaching, physical training, studios, and residencies. As Hannan (2001, p. 1) argued, "many other resource-hungry fields such as science, medicine and engineering do not see why they should be subsidizing a music school."

A decade later, Newfield (2008, p. 15) reflected on the period since 2000 as a time in which university "cultural missions have declined at the same time as leaders in politics, economics and the media have lost much of their capacity to understand the world in noneconomic terms." Thornton (2008, p. 5) further explored this link between economics and research management, suggesting that knowledge within the current university environment "has replaced sheep and wool as a source of wealth but, according to the corporatised university, academics, like sheep, require careful management to get the best out of them". Whilst the research frameworks designed to manage and assess research differ according to location, traditionally notated "scientific" research remains the accepted norm. This has particular implications for the humanities wherein innovative and non-traditional modes of research approach and output need to be accommodated within much less flexible frameworks. 
Research assessment also reflects a shift in university funding from largely government sources to a mix of government and earned income. In 1996, Australian state and federal governments provided approximately $58 \%$ of all funds to universities with the remainder coming from fees, charges, bequests, research income and other sources. By 2005 the government provided only $40 \%$ of university funds (Universities Australia, 2009). The growing need for earned income explains the focus on income generated through high-level research activities, and high income-producing courses.

Trends such as these have led many governments to formally assess academic output, and this has necessitated the development of complex assessment frameworks. The most recent of these in Australia is Excellence for Research in Australia (ERA), which was announced in February 2008 by the then Minister for Innovation, Industry, Science and Research, the Honorary Senator Kim Carr. A comprehensive research quality and evaluation system, ERA had an initial annual budget of AUD $\$ 35.8$ million. It was trialled in 2009 and fully implemented in 2010, and the results of the first round were released in February 2011. The objectives of the ERA are to:

- Establish an evaluation framework;

- Provide a national stock-take of research to identify research strengths and opportunities;

- Identify excellence in research;

- Identify emerging areas; and

- Benchmark research nationally and internationally.

Unique to the ERA is the ranking of research journals and the associated implication that articles published in highly ranked journals are better than those published elsewhere. It is almost certain that most Australian academics are now thinking about how they can publish within identified and preferred channels: "steered towards publishing in preferred journals and 'lambasted for their inadequacy if they do not"' (Rowbotham, 2011, n. p). A further consideration is the potential loss of the independent scholarly voice, in that "the application of a rational framework to research activity does away only with those social values which differ from the dominant values in the academic community" (Brew, 2001, p. 86).

Recognition of a wide range of research outputs is not new in Australia, which until the 1990s funded twenty categories of research output, including artistic research, until an independent audit identified inconsistencies in $45 \%$ of claims. After a decade in which only authored books, peer reviewed journal articles, refereed conference papers and book chapters were recognised as research, artistic research is now recognised in four categories:

- Original (creative) works in the public domain;

- Live performance works in the public domain;

- Recorded (performance) public works; and

- Curated or produced substantial public exhibitions, events or renderings. (Australian Research Council, 2008)

The inclusion of artistic research in Australia aligns with an international trend. In the UK, for example, artistic research became eligible for funding in 1992 with the implementation of the Research Assessment Exercise (RAE), soon to be replaced by its successor, the Research Excellence Framework (REF). Despite this history, many of the difficulties relating 
to the inclusion of artistic research are common to multiple frameworks and remain unresolved.

\section{Implications}

The issues presented here highlight a number of challenges, and I focus here on two of these. First is the ability of research frameworks to accommodate artistic research output in its many forms. At the most basic level, research output has to be evidenced if it is to be assessed. Whilst this can be a relatively simple process for traditional outputs such as journal articles, accumulating the evidence required for artistic research can be complex and demanding. In the recent Australian experience this was further complicated by the need to retrospectively amass the evidence for outputs dating back to 2003. Academics trawled through boxes for exhibition catalogues, through newspaper archives for reviews, and through concert programs for evidence of a performance. Universities developed dark archives to accommodate confidential materials, and additional capacity to accommodate digital outputs.

The management implications of this aspect have been largely logistical and financial. A much more vital issue, and one that requires attention over an extended period, is that artistic research output is not generally well understood. Indeed, its complexity makes it difficult to accommodate in a scheme of this sort. For students and academics alike, articulation of the often-fluid process has rarely been assisted by super-imposing research questions. Alongside this, the previous lack of recognition for artistic research in Australia has resulted in the demise of much artistic practice and to a separation of artistic and academic roles. Reengagement is likely to take time, and it will require continued mentorship and institutional support (Bennett, Blom and Wright, 2009).

The second challenge discussed here is the challenge of translating artistic research into a form that can be more widely understood as well as assessed. Assessment within the Australian framework requires each artistic work to be accompanied by a 250 -word written narrative that articulates each work's research background, its contribution to new knowledge and its research significance. The articulation of artistic work as research poses conceptual and philosophical challenges, particularly for academics whose artistic output is not in the written word. One academic transcribed the process as akin to translating the work into another language for a culture where the rules are all different [personal communication]. The requirement for a written narrative highlights a focus on public recognition in the form of, for example, reviews in the national media. This is at odds with the peer recognition that legitimises research in most other areas, notably the sciences. It poses a practical dilemma as well as an ethical one; peer assessment raises difficult questions about who will assess public recognition and quality, and how this process can be made transparent and transferable across the sector.

Whilst the inclusion of artistic research has been applauded it has not been without its problems, and many of these were articulated in the UK before implementation of the Australian ERA (Wright, Bennett \& Blom, 2010). As Niedderer and Roworth-Stokes wrote in 2007 (p. 5), by

opening research to the inclusion of [artistic] practice, the need arose to legitimise the use of practice within research and with regard to its contribution to knowledge, because 
the requirements for research remained the same, and any submission was and still is judged against the conventional criteria for rigor and validity of research.

Management of this aspect has included practical approaches such as peer mentorship and exemplars for the research statements. On a deeper level, it has involved in-depth discussion of the process (often hidden or embodied, and at times accidental or spontaneous) that led to the work itself. For some academics the unexplored, intangible facets of the creative process are sacred: potentially threatened if subjected to analysis. In these cases it has at times been necessary to create research opportunities away from the practice itself: for example, in the teaching of the process to students.

There are obvious implications here for higher degree by research students. As Freeman (2010, p. 65) explains, there is a need distinguish between "practice as research" and "research for practice": the "tension between the ephemeral qualities of performance and the permanence of a thesis ... puts the search into research". As can be seen, artistic research has attracted considerable attention as frameworks have sought to "regularize creative practice - dissect, section and give acceptable academic shape to it" (Rosenberg, 2008, p. 5). The implications of this for artistic practice include the need to ensure that academics do not find themselves and their students "driven by the external art world and educational agendas that rarely reflect their own artistic motives and practice" (Carroll, 2006, n. p). Overall, management of humanities knowledge will require the development of new modes of communication between and across disciplines. It will necessitate the review of traditional curricula to ensure their reach beyond disciplinary boundaries. And it will need creativity and courage to support individual academics as they build on interests and strengths.

\section{Concluding Comments}

New humanities scholars within and beyond the creative arts analyse not only the subject of their research, but the relationships - or potential relationships - of that subject with the external environment, considering aspects such as purpose, reception, use and impact. In so doing they create what Dawson (2006) describes as 'sociological poetics' that link research with the outside world. This differs from traditional scientific research in that humanities researchers rarely analyse something without looking beyond it. And yet looking beyond it invariably entails working across disciplinary boundaries. The call to diminish these boundaries is far from new: Kuhn argued in 1962 against making divisions of knowledge, including distinctions such as subjective and objective, humanities and science, and argued instead for a new 'fuzziness' to erase existing oppositions. For Australian researchers this might seem the antithesis of the ERA with its 1,238 fields of research. Aristotle's broad subject base would certainly not be well received within the ERA ranking process, but then the ability to transcend boundaries is perhaps what most defines making and managing knowledge in the new humanities. 


\section{References}

Australian Academy of the Humanities. (2009). The humanities in Australia today. Retrieved December 10, 2010, from http://www.humanities.org.au/Policy/HumanitiesToday.html

Australian Research Council. (2008). ERA Indicator Descriptors. Retrieved May 1, 2010, from http://www.arc.gov.au/pdf/ERA_Indicator_Descriptors.pdf

Bennett, D., Blom, D., \& Wright, D. (2009). Artist academics: Performing the Australian research agenda. International Journal of Education and the Arts, 10(17). Retrieved May 22nd, 2009, from http://www.ijea.org/v10n17/index.html

Brew, A. (2001). The nature of research. London: Routledge/Falmer.

Carroll, J. (2006). An investigation of the relation between artistic practice, teaching practice and research in universities. Working Papers in Art and Design, 4. Retrieved October 8, 2009, from http://www.herts.ac.uk/artdes/research/papers/wpades/vol4/jcfull.html

Dawkins, J. (1998). Higher education policy. A policy statement. Canberra, ACT: Australian Government Publishing Service.

Dawson, P. (2006). Negotiating the creative and the critical: Paul Dawson's creative writing and the new humanities. [Review of the book Creative writing and the new humanities]. Australian Humanities Review, 39-40.

Fish, S. (2008, January 6). Will the humanities save us? [Blogpost]. Message posted to http://fish.blogs.nytimes.com/2008/01/06/will-the-humanities-save-us/\#more-81

Freeman, J. (2010). Blood, sweat and theory. Libri Publishing: Oxfordshire.

Hannan, M. (2001). The future of tertiary music training in Australia. Australian Music Forum, 7(3).

Humanities in the United States. (2010). Retrieved February 6, 2011, from http://en.wikipedia.org/wiki/Humanities_in_the_United_States

Ianziti, G. (2007, May 10). Traditional humanities out: Creative industries in. [Blogpost]. Message posted to http://www.onlineopinion.com.au/view.asp?article $=5832$

Joseph, M. (2002). The trivium: The liberal arts of logic, grammar, and rhetoric (M. McGlinn, Ed.). Paul Dry Books: Philadelphia.

Kuhn, T. (1962). The structure of scientific revolutions. The University of Chicago Press: Chicago.

Levi, A. W. (1970). The humanities today. Indiana University Press: Bloomington.

Newfield, C. (2008). Unmaking the public university. Cambridge, Mass.: Harvard University Press.

Niedderer, K., \& Roworth-Stokes, S. (2007). The role and use of creative practice in research and its contribution to knowledge. Unpublished paper presented at the International Association of Societies of Design Research. Hong Kong: Hong Kong Polytechnic University.

Princeton University 2011, WordNet: A lexical database for English. Humanities. Retrieved February 14, 2011, from http://wordnet.princeton.edu

Rosenberg, T. (2008). Worthy of Gordius: The knotty problem of configuring creative practice as research, or indeed research for creative practice. Unpublished paper presented at On Artistic Research. Reykjavík: Icelandic Academy of the Arts.

Rowbotham, J. (2011, March 2). Journal rankings a sword over universities. The Australian, retrieved March 2, 2011, from http://www.theaustralian.com.au/higher-education/journal-rankings-asword-over-universities/story-e6frgcjx-1226014363796

Shumway, D. R. (2007). What are the Humanities? Focus, 36(6), pp. 1, 6.

Stanford University 2011, What are the humanities? Retrieved February 14, 2011, from http://humanexperience.stanford.edu/what

Thornton, M. (2008). The retreat from the critical: Social science research in the corporatised university. Australian Universities Review, 50(1), 5-10.

Tymoczko, M. (2001). Will the traditional humanities survive in the $21^{\text {st }}$ century? Organization, $8(2)$, 285-297. 
Universities Australia. (2009). Retrieved August 11, 2009, from http://www.universitiesaustralia.edu.au/content.asp?page=/universities/overview.htm

Wright, D., Bennett, D., \& Blom, D. (2010). The interface between arts practice and research: Attitudes and perceptions of Australian artist-academics. Higher Education Research and Development, 29(4), 461-473.

\section{About the Author}

Assoc. Prof. Dawn Bennett

Associate Professor Dawn Bennett is a Senior Research Fellow and Director of the Creative Workforce initiative at Curtin University in Perth, Australia. She has authored over 50 publications in the areas of music education, careers, academic life and the creative workforce, including Understanding the Classical Music Profession: The Past, the Present and Strategies for the Future (Ashgate). Dawn serves on the editorial boards of the International Journal of Music Education and the Australian Journal of Music Education. She is a member of the Music Council of Australia, a commissioner for the ISME Teaching and Learning Forum, and editor of the Society's newsletter. 


\section{JOURERALAL Of THE HUMANITIES}

$O M M O N$

\section{Editors}

Tom Nairn, The Globalism Institute, RMIT University, Australia.

Mary Kalantzis, University of Illinois, Urbana-Champaign, USA.

\section{Editorial Advisory Board}

Patrick Baert, Cambridge University, Cambridge, UK.

David Christian, San Diego State University, San Diego, USA.

Bill Cope, University of Illinois, Urbana-Champaign, USA.

Joan Copjec, State University of New York, Buffalo, USA.

Alice Craven, American University of Paris, Paris, France.

Michel Demyen, University of Victoria, Victoria, Canada.

Elizabeth DePoy, University of Maine, Orono, USA

Mick Dodson, Australian National University, Canberra, Australia.

Oliver Feltham, American University of Paris, Paris, France.

Clyde R. Forsberg Jr., Oxford College/Aletheia University, Tamsui, Taiwan.

Stephen French Gilson, University of Maine, Orono, USA.

Hafedh Halila, Institut Supérieur des Langues de Tunis, Tunis, Tunisia.

Souad Halila, University of Tunis, Tunis, Tunisia.

Hassan Hanafi Hassanien, Cairo University, Cairo, Egypt.

Ted Honderich, University College, London, UK.

Paul James, Globalism Institute, RMIT University, Melbourne, Australia.

Moncef Jazzar, Institut Supérieur des Langues de Tunis, Tunis, Tunisia.

Eleni Karantzola, University of the Aegean, Rhodes, Greece.

Krishan Kumar, University of Virginia, Charlottesville, USA.

Ayat Labadi, Institut Supérieur des Langues de Tunis, Tunis, Tunisia.

Marion Ledwig, University of Nevada, Las Vegas, USA.

Greg Levine, Macquarie University, Sydney, Australia.

Harry R. Lewis, Harvard University, Cambridge, USA.

Fethi Mansouri, Institute for Citizenship \& Globalization, Deakin University, Melbourne, Australia.

Juliet Mitchell, Cambridge University, Cambridge, UK.

Nahid Mozaffari, New York, USA.

Nikos Papastergiadis, University of Melbourne, Melbourne, Australia.

Robert Pascoe, Victoria University, Melbourne, Australia.

Scott Schaffer, University of Western Ontario, London, Canada.

Jeffrey T. Schnapp, Stanford University, Stanford, USA.

Gayatri Chakravorty Spivak, Columbia University, New York, USA.

Bassam Tibi, University of Goettingen, Goettingen, Germany and

Cornell University, Ithaca, USA.

Giorgos Tsiakalos, Aristotle University of Thessaloniki, Thessaloniki, Greece.

Siva Vaidhyanathan, University of Virginia, Charlottesville, USA.

Cheryl A. Wells, University of Wyoming, Laramie, USA.

Zhang Zhiqiang, Nanjing University, Nanjing, People's Republic of China.

Chris Ziguras, Globalism Institute, RMIT University, Melbourne, Australia. 


\section{The Humanities Community}

This knowledge community is brought together by a shared commitment to the humanities and a concern for their future. The community interacts through an innovative, annual face-to-face conference, as well as year-round virtual relationships in a weblog, peer reviewed journal and book imprint - exploring the affordances of the new digital media. Members of this knowledge community include academics, educators and research students.

\section{Conference}

Members of the Humanities Community meet at the International Conference on New Directions in the Humanities, held annually in different locations around the world.

Over the past eight years, the Humanities Conference has established a reputation as a focal point for new ideas and new practices in humanities research and teaching. The conference was held at the University of California, Los Angeles, USA in 2010; in Beijing, China in 2009; the Fatih University, Istanbul, Turkey in 2008; American University of Paris in 2007; University of Carthage, Tunis, Tunisia in 2006; University of Cambridge, Cambridge, UK in 2005; Monash University Centre, Prato, Italy in 2004; and the University of the Aegean, Rhodes, Greece in 2003. In 2011, the conference will be held at the Universidad de Granada, Granada, Spain.

Online presentations can be viewed on YouTube.

\section{Publishing}

The Humanities Community enables members to publish through three media. First, by participating in the Humanities Conference, community members can enter a world of journal publication unlike the traditional academic publishing forums - a result of the responsive, non-hierarchical and constructive nature of the peer review process. The International Journal of the Humanities provides a framework for double-blind peer review, enabling authors to publish into an academic journal of the highest standard.

The second publication medium is through a book series The Humanities, publishing cutting edge books in print and electronic formats. Publication proposals and manuscript submissions are welcome.

The third major publishing medium is our news blog, constantly publishing short news updates from the Humanities community, as well as major developments in the humanities. You can also join this conversation at Facebook and Twitter or subscribe to our email Newsletter. 


\section{Common Ground Publishing Journals}

\begin{tabular}{|c|c|}
\hline $\begin{array}{l}\text { AGING } \\
\text { Aging and Society: An Interdisciplinary Journal } \\
\text { Website: http://AgingAndSociety.com/journal/ }\end{array}$ & $\begin{array}{c}\text { ARTS } \\
\text { The International Journal of the Arts in Society. } \\
\text { Website: www.Arts-Journal.com }\end{array}$ \\
\hline $\begin{array}{c}\text { BOOK } \\
\text { The International Journal of the Book } \\
\text { Website: www.Book-Journal.com }\end{array}$ & $\begin{array}{c}\text { CLIMATE CHANGE } \\
\text { The International Journal of Climate Change: } \\
\text { Impacts and Responses } \\
\text { Website: www.Climate-Journal.com }\end{array}$ \\
\hline $\begin{array}{c}\text { CONSTRUCTED ENVIRONMENT } \\
\text { The International Journal of the } \\
\text { Constructed Environment } \\
\text { Website: www.ConstructedEnvironment.com/journal }\end{array}$ & $\begin{array}{c}\text { DESIGN } \\
\text { Design Principles and Practices: } \\
\text { An International Journal } \\
\text { Website: www.Design-Journal.com }\end{array}$ \\
\hline $\begin{array}{c}\text { DIVERSITY } \\
\text { The International Journal of Diversity in } \\
\text { Organizations, Communities and Nations } \\
\text { Website: www.Diversity-Journal.com }\end{array}$ & $\begin{array}{l}\text { FOOD } \\
\text { Food Studies: An Interdisciplinary Journal } \\
\text { Website: http://Food-Studies.com/journal/ }\end{array}$ \\
\hline $\begin{array}{c}\text { GLOBAL STUDIES } \\
\text { The Global Studies Journal } \\
\text { Website: www.GlobalStudiesJournal.com }\end{array}$ & $\begin{array}{c}\text { HEALTH } \\
\text { The International Journal of Health, } \\
\text { Wellness and Society } \\
\text { Website: www.HealthandSociety.com/journal }\end{array}$ \\
\hline $\begin{array}{c}\text { HUMANITIES } \\
\text { The International Journal of the Humanities } \\
\text { Website: www.Humanities-Journal.com }\end{array}$ & $\begin{array}{c}\text { IMAGE } \\
\text { The International Journal of the Image } \\
\text { Website: www.Onthelmage.com/journal }\end{array}$ \\
\hline $\begin{array}{l}\text { LEARNING } \\
\text { The International Journal of Learning. } \\
\text { Website: www.Learning-Journal.com }\end{array}$ & $\begin{array}{c}\text { MANAGEMENT } \\
\text { The International Journal of Knowledge, } \\
\text { Culture and Change Management. } \\
\text { Website: www.Management-Journal.com }\end{array}$ \\
\hline $\begin{array}{c}\text { MUSEUM } \\
\text { The International Journal of the Inclusive Museum } \\
\text { Website: www.Museum-Journal.com }\end{array}$ & $\begin{array}{c}\text { RELIGION AND SPIRITUALITY } \\
\text { The International Journal of Religion and } \\
\text { Spirituality in Society } \\
\text { Website: www.Religion-Journal.com }\end{array}$ \\
\hline $\begin{array}{c}\text { SCIENCE IN SOCIETY } \\
\text { The International Journal of Science in Society } \\
\text { Website: www.ScienceinSocietyJournal.com }\end{array}$ & $\begin{array}{c}\text { SOCIAL SCIENCES } \\
\text { The International Journal of Interdisciplinary } \\
\text { Social Sciences } \\
\text { Website: www.SocialSciences-Journal.com }\end{array}$ \\
\hline $\begin{array}{c}\text { SPACES AND FLOWS } \\
\text { Spaces and Flows: An International Journal of } \\
\text { Urban and ExtraUrban Studies } \\
\text { Website: www.SpacesJournal.com }\end{array}$ & $\begin{array}{c}\text { SPORT AND SOCIETY } \\
\text { The International Journal of Sport and Society } \\
\text { Website: www.sportandsociety.com/journal }\end{array}$ \\
\hline $\begin{array}{c}\text { SUSTAINABILITY } \\
\text { The International Journal of Environmental, Cultural, } \\
\text { Economic and Social Sustainability } \\
\text { Website: www.Sustainability-Journal.com }\end{array}$ & $\begin{array}{c}\text { TECHNOLOGY } \\
\text { The International Journal of Technology, } \\
\text { Knowledge and Society } \\
\text { Website: www.Technology-Journal.com }\end{array}$ \\
\hline $\begin{array}{c}\text { UBIQUITOUS LEARNING } \\
\text { Ubiquitous Learning: An International Journal } \\
\text { Website: www.ubi-learn.com/journal/ }\end{array}$ & $\begin{array}{l}\text { UNIVERSITIES } \\
\text { Journal of the World Universities Forum } \\
\text { Website: www.Universities-Journal.com }\end{array}$ \\
\hline
\end{tabular}

